\title{
On Social and Psychological Consequences of Prolonged Poverty-A Longitudinal Narrative Study From Finland
}

\author{
Anna-Maria Isola ${ }^{1,2}$, Lotta Virrankari ${ }^{1}$, Heikki Hiilamo ${ }^{1,3}$ \\ [1] Public health and welfare, Finnish institute for health and welfare, Helsinki, Finland. [2] Social work, University of Turku, Turku, Finland. [3] Social policy, \\ University of Helsinki, Helsinki, Finland.
}

Journal of Social and Political Psychology, 2021, Vol. 9(2), 654-670, https://doi.org/10.5964/jspp.7615

Received: 2019-12-01 • Accepted: 2021-06-08 • Published (VoR): 2021-12-15

Handling Editor: Kesi Mahendran, The Open University, Milton Keynes, United Kingdom

Corresponding Author: Anna-Maria Isola, Finnish institute for health and welfare, Public health and welfare, Mannerheimintie 166, 00270 Helsinki, Finland. E-mail: anna-maria.isola@thl.fi

Supplementary Materials: Data, Materials [see Index of Supplementary Materials]

\begin{abstract}
By means of qualitative longitudinal material, this article explores meaningfulness during persistent monetary poverty through an integrative framework, which builds upon conceptualisations of meaning in life (coherence, significance, and purpose) and modes of being (labour, work, action). The material consists of 36 autobiographical accounts and their follow-up accounts from 2006 and 2012. The analysis reveals that in the developed welfare state of Finland, prolonged monetary poverty is connected with the propensity for incoherence and a feeling of insignificance, particularly if life is governed by a vicious cycle of scarcity. Prolonged poverty 1) turns aspirations from long-term to short-term goals and frames life as something characterised by negative anticipation and a circular sense of time. Life primarily takes place in private space. It also 2) weakens the sense of belonging and 3) reduces public participation. These are the domains where the meaning in life is constructed, deconstructed, and reconstructed. In a developed welfare state, the comprehensive and manageable social security scheme maintains coherence, yet universal social policy actions that enable participation in public activities nourish a sense of significance.
\end{abstract}

\section{Keywords}

welfare state, poverty, longitudinal qualitative research, psychological consequences, social consequences, meaningfulness

In the end, nothing interested me, I couldn't manage to see my friends or keep up with the hobbies. Days passed by, grey and unchanging. It was like trudging in a marsh, like a spider web one gets caught in. I neglected my studies. I didn't care about my health or well-being. Nothing mattered. I was nervous and anguished. I couldn't see the future.

(A female respondent in Everyday Experiences of Poverty in Finland, 2012)

In their accounts, Finnish poor people described that their daily pursuits revolved around repetitive activities. Moreover, uncertainties and a sense of meaninglessness also seemed to over-govern their lives. These feelings were concealed in small stories within autobiographical poverty narratives. This preliminary perception was salient as it made us ask what happens to the mode of being and meaningfulness during prolonged poverty. By extracting and analysing the small stories from the longitudinal narrative material with the conceptualization of meaning in life (Martela \& Steger, 2016) and by interpreting the findings through an Arendtian approach to modes of being (Arendt, 1958/1998), we contribute to the academic discussion on the social and psychological implications of prolonged monetary poverty in a developed welfare state. 
As to a minimum welfare provision, poverty in a developed welfare state is, by and large, relative and only seldom absolute (see Townsend, 1979). This applies to Finland, too, where income-poor people are more or less able to satisfy their basic needs but not participate in the minimum acceptable way of life. However, in certain circumstances, relative poverty alone may have severe consequences.

Previous studies have connected income-poverty to weakening friendships and family relationships (Mood \& Jonsson, 2016), depression, self-deprecation, and withdrawal from social situations (Beresford, Green, Lister, \& Woodward, 1999), declining political participation (Desmond \& Travis, 2018; Mattila, Rapeli, Wass, \& Söderlund, 2017; Mood \& Jonsson, 2016), a loss of recognition (Schweiger, 2013), shame, and stigma (Walker, 2014). Stigma may be both externalised and internalised. The former is a mechanism by which other people may discriminate against poor people and consider them a burden to society. The latter is the shame caused by the failure to participate in average everyday life (Reutter et al., 2009). A study from India and the U.S. demonstrated that people who defined themselves as poor disregarded challenging labour tasks (Banker, Bhanot, \& Deshpande, 2020).

Social identity theory (Tajfel, 1978) holds that one constructs a social identity through intergroup comparisons. A study from Turkey showed that poor people aspired to identify with higher status groups when there was an unstable social structure. Conversely, they employed creative strategies in a stable social structure, such as defining themselves with more positive than negative attributes (Akfirat, Polat, \& Yetim, 2016). In the context of a developed welfare state, a study from Scotland and England indicated, in turn, that low-income people tended to reject discourses that stereotyped poor people (Pemberton, Fahmy, Sutton, \& Bell, 2016). Although poor people in developed welfare states resist poverty identity, they have a propensity to make detrimental social comparisons. A status syndrome, an underlying condition with constant stress, threatens people's wellbeing and health if they find themselves in a situation of income-poverty (Marmot, 2015). Based primarily on work by behavioural economists (Bertrand, Mullainathan, \& Shafir, 2004; Hall, Zhao, \& Shafir, 2014; Mani, Mullainathan, Shafir, \& Zhao, 2013, see also Haushofer \& Fehr, 2014), in their theoretical model Zhao and Tomm (2018) have described how a vicious cycle of scarcity and a persistent lack of money deepen social and psychological difficulties.

In this article, we explore how prolonged poverty, and within which domains, affects meaning in life and the mode of being. The former serves as an analytical and the latter as an interpretative framework. Finally, we elaborate on the vicious cycle of scarcity outlined by Zhao and Tomm (2018) with the findings that this article brings up for discussion.

\section{The Analytical and the Interpretative Framework: Meaning in Life and Modes of Being}

Meaningfulness is a concept that is typically used in the field of social and positive psychology, and it underpins the quality of life (Bernard, Braunschweig, Fegg, \& Borasio, 2015; Martela, 2017). We approach it through a sense of coherence (Antonovsky, 1979, 1987), self-determination theory (Deci \& Ryan, 1985; Ryan \& Deci, 2000) and meaning in life (Martela \& Steger, 2016) (see Table 1).

Table 1

The Central Concepts of Meaning in Life

\begin{tabular}{llll}
\hline Theory & Sense of coherence & Self-determination theory & Meaning in life \\
\hline Central concepts & Comprehensibility & Autonomy & Coherence (present) \\
& Manageability & Competence & Significance (present, past, future) \\
& Meaningfulness & Relatedness & Purpose (future) \\
& & Benevolence & Frank Martela and Michael Steger \\
Researcher/s & Aaron Antonovsky (1987) & Richard Ryan and Edvard Deci & $(2016)$ \\
& & $(2000) ;$ Frank Martela and Richard & Ryan (2016) \\
\hline
\end{tabular}


A sense of coherence is a central part of the salutogenic health model, which Antonovsky developed to explain social and psychological health determinants. A sense of coherence has three components: comprehensibility, manageability, and meaningfulness. Following Antonovsky's (1987, p. 19) approach, coherence expresses the extent to which one has a feeling of confidence that internal and external environments are structural, predictable, understandable, and explicable. Coherence also reflects the beliefs as to whether one has sufficient resources available to engage in desired actions.

In their self-determination theory, Ryan and Deci (2000) focused on the social conditions that enhance self-motivation. In this theory, autonomy, competence, and relatedness are psychological factors that promote positive psychological development. Autonomy covers the freedom to manage one's life without external coercion. Competence incorporates experiencing mastery and receiving feedback on one's actions. Relatedness refers to a variety of social relations and relationships. Based on an empirical analysis, Martela and Ryan (2016) have added benevolence as the fourth psychological factor of self-determination theory.

Seen from afar, Antonovsky (1987), Ryan and Deci (2000), and Martela and Ryan (2016) relate to the same idea, yet they conceptualise it differently: overall, a sense of coherence and self-determination both describe factors that take human life forward and maintain the quality of life (Martela, Ryan, \& Steger, 2018). Martela and Steger (2016) have fused an admixture of philosophical and empirical ingredients from previous academic work into the conception meaning in life and have divided it into three facets: coherence, significance, and purpose.

In their conceptualisation, coherence covers making sense of the world in a cognitive and value-neutral manner. It refers to understanding of one's life and its internal and external environments, as Antonovsky (1987) earlier explained. Significance creates motivation. It thus falls closest to what Deci and Ryan (1985) have theorised about self-determination. Purpose is connected with values and the direction of life. Sensing purpose motivates one to find valuable short-term and long-term goals. It thus broadens and lengthens one's prospects (Martela \& Steger, 2016). Compared to Antonovsky's (1985) or Ryan's and Deci's thoughts (2000), Martela and Steger (2016) specifically emphasise that meaning in life is anchored in temporal structures. While value-laden purpose sustains the direction of life and creates long-term prospects, coherence is constructed from the here and now. Feelings or experiences of significance are primarily determined by present activities, but may also change the subjectively evaluated importance of past and future activities (Martela \& Steger, 2016, pp. 533-536).

Meanwhile, we approach all the aforesaid through Hannah Arendt's (1958/1998) classification of the three modes of being: (1) labour occurs in private space. Its activities are repetitive and circular in nature. While the time of labour is circular, (2) it is linear in work. Labour "produces anything but life", whereas work is an instrument with which to put the reproductive and biological conditions of life aside. Work produces an objective, permanent, and shared world (Arendt, 1958/1998, pp. 79-248). Zhao and Tomm (2018) state that a lack of money draws cognitive resources to urgent demands, then disturbs other domains of life and eventually may lead to prioritising short-term gains over long-term ones (see also Mani, Mullainathan, Shafir, \& Zhao, 2013; Bertrand, Mullainathan, \& Shafir, 2004; Haushofer \& Fehr, 2014). This falls in line with an Arendtian sense of reproductive and productive modes of life and how the movement from the productive to reproductive mode of being (or vice versa) takes place.

Arendt claims that only emancipation from the biological body (reproduction) and instrumental world (production) together with performing actions in the shared world and particularly in public space may bring meaning and purpose to life (Arendt, 1958/1998, pp. 115, 120-121, 145, 215, 288). Thus, (3) action is the highest mode of being. It takes place in interaction between free people in public space where people come together, encounter and see each other and engage in activities together. Action is the medium with which one can be signified by others as a recognisable individual. Nancy Fraser (2009, pp. 112-114; see also Lister, 2004) approaches this by means of participation and parity of participation and maintains that poor people live in less effective conditions for really being able to participate in public spaces, public discussion, and politics.

\section{The Contextual Framework: The Finnish Welfare State}

The constitution of Finland guarantees that "those who cannot obtain the means necessary for a life of dignity have the right to receive indispensable subsistence and care" (The Constitution of Finland, 1999, section 19). Overall, the Finnish 
welfare state aims to cover social risks. If a risk-such as ageing, unemployment, sickness, disability or having a childends up being actualised, the welfare state will compensate the income loss to a certain extent. The two-layered primary system defines the monetary level of the benefits. Basic-level transfers are paid by the Social Insurance Institution while earnings-related transfers are managed by tripartite institutions (Kosonen, 1993; Kuivalainen \& Niemelä, 2010). If one does not have the right to a primary, risk-based benefit offering income replacement in relation to one's previous wage, one may be eligible for a means-tested income allowance. This is often the case when long-term unemployed people have exhausted their right to earnings-related unemployment compensation and when young people without a work history enter the labour market but cannot find work.

Traditionally, it was the local municipality or parish that was responsible for collecting taxes, delivering aid to the poor, and other basic public good. The local level played a crucial role in the provision of public services for a long time afterwards, until the development of the universal welfare state in Finland began in the 1960s (Hiilamo, Kangas, Fritzell, Kvist, \& Palme, 2013). It came to include not just comprehensive income replacement programmes against social risks but also to embrace construction of tuition-free and high-quality education on all levels (including adult education) and included the provision of public libraries (Kosonen, 1993). During the golden years of the development of the welfare state in the 1970s and 1980s, Finland was able to unify the pursuit of equality and social cohesion with an efficient welfare state and a high level of taxation (Esping-Andersen, 1990).

All the Nordic countries experienced a deep economic recession in the early 1990s. The Finnish welfare system was put to the test (Hiilamo, 2012; Kiander, 2005). Faced with the collapse of banks and uncontrollable budget deficits, the government introduced austerity programmes that cut benefits and raised taxes. The number of cases of prolonged poverty-that is, living below the poverty line continuously for at least two years-almost doubled from 1998 to 2012 (OSF, 2006). Structural unemployment had become a permanent phenomenon in Finnish society as well (Larsen, 2013; Ministry of Economic Affairs and Employment of Finland, 2019).

During the time of crises in the 1990s, civil sector actors came up with new solutions to poverty-related problems such as over-indebtedness and homelessness. For example, poverty alleviation in terms of financial assistance and the distribution of food became the dominant features of NGOs and faith-based organisations (Hiilamo, 2012). The development continued during and after the economic collapse of 2008. Whereas earlier poverty relief leant on universal institutions, after the recessions it took a step towards a welfare state mixed approach, in which the role of public actors and civil society actors, including volunteers, is recognised (Leis-Peters, 2014). Furthermore, a more targeted approach with piecemeal reforms was chosen to alleviate relative poverty. A moderate transition from universalism to selectivism is taking place in Finland (Anttonen \& Sipilä, 2012; Hellman, Monni, \& Alanko, 2017; Kettunen, 2006; Kuivalainen \& Nelson, 2012; Stefánsson, 2012).

From a comparative perspective, despite the change in policy direction to combat poverty, Finland along with other Nordic countries has been one of the most successful nations in providing equal opportunities for all citizens regardless of their socio-economic background. Absolute poverty is practically eradicated due to the basic-level benefits. Similarly, the relative poverty rate in Finland has been among the lowest in cross-national comparisons. It is combated with active employment-promoting policies combined with an encompassing system of social benefits (Hiilamo, 2012; Korpi \& Palme, 1998).

\section{The Longitudinal Narrative Research Setting}

\section{Material Information: Features, Choices, and Limitations}

The material of this study consists of the 36 autobiographical accounts and their follow-up accounts that were selected from a total of 850 accounts by respondents who partook in the writing contest 'Everyday Experiences of Poverty in Finland' in 2006 (see Supplementary Materials). The material consists of 153 pages with line spacing of 1.15 and a font size of 11 . 
The following instructions were given in 2006:

We hope that you write freely about how poverty has come into your life and about what means you use to get by in everyday life. You can write as if you were telling a close friend about your life. [...] It is important that you write about your own experiences and that you tell us what time in your life your experiences are about. (Instructions, 2006)

A follow-up collection was arranged in 2012. From amongst the 850 respondents in 2006, 362 were selected (306 women and $56 \mathrm{men})$. They were sent the following call for submission:

What kinds of things have happened that you think are essential for managing your life? What kind of ups and downs have you faced in your life? From where have you received support? You can consider your life in relation to, for example, work, family, hobbies, living conditions and coping. (Call for submission, 2012)

Altogether 141 respondents sent a follow-up account, of which every seventh was a male respondent. With the help of key codes (which one of the organisers maintained), the texts from 2012 were brought together with texts written in 2006 by the same respondents. The accounts were dealt with as a panel and not as an individualised matter.

The accounts written in 2012 were categorised into three groups based on the respondent's evaluation of the change in the quality of life. Prior to this, 62 accounts were excluded from the material using pre-determined criteria: Poems and novels narrated in the third person $(n=13)$ were taken out. Then the accounts written by people aged 65 years old or more $(n=31)$, accounts with vague evaluations of the change in the quality of life $(n=13)$, or otherwise unclear texts $(n=5)$ were removed. After this, there were a total of 79 accounts, of which 39 accounts included positive evaluation of the change in the quality of life, 28 accounts contained no remarkable change, and 12 accounts included a negative change in life. Of these, a total of 12 of the most relevant accounts per category were selected (see Background Information, Table A.1 in the Appendix).

Oral and written narratives are reflected representations of lived lives. Oral stories are typically based on paradigmatic logic. This means that a storyteller may detach herself or himself from a chronological plot and then randomly tie and fit together memories over the course of her or his life. Written stories, in turn, are mainly structured through syntagmatic logic whereby a storyteller aims to present the selection of events in chronological order (Hastrup, 1987). Positive transitions may be slightly emphasised in our material, as the writing instruction given in 2012 explicitly speaks of "managing life". This may have channelled the respondents to choose positive episodes from their lives, of which, following the syntagmatic logic of written storytelling, they then constructed their autobiographical accounts. By the same token, bias towards positive transitions may be explained by the fact that the respondents' incomes have actually increased by a subjectively significant, however, objectively small sum. Alternatively, the respondents' quality of live may have improved. Whatever the explanation is, the analysis is not skewed by the bias, as the prevalence of poverty was not the focus.

The following excerpts illustrate how the accounts were categorised into three groups:

"During the last six years, my life has been going downhill. My health, coping resources and livelihood.” (Negative change.)

"My husband became unemployed after working for two years. The same vicious cycle continues. Sometimes there are some glimpses of joy, but normally nothing other than misery." (No remarkable change.)

"My financial situation has improved in small steps and suddenly I have notice that my dreams and necessary commodities have increased." (Positive change.)

Given that objective indicators such as the poverty line and employment status were not relied upon alone, the respondent's evaluation was necessary. However, a few accounts, such as the one below, were subjected to the interpretation; all of them fell into the group of no remarkable change. For instance, in the following account, objective and subjective indicators told a different story: 
Over the course of these six years, to my mind, I have financially managed my life well and I have not even had any experiences of poverty, although according to poverty indicators, I am supposed to be a poor person. Conversely, I have had the wealthiest years of my life, measured in money. However, I have had no opportunities to demonstrate all of my competence in working life. I am without permanent housing and permanent work. This is my own choice though. (No remarkable change.)

We focused on small stories dealing with meaning in life within three different contexts involving a change in the quality of life during prolonged financial poverty in the Finnish welfare state. By small stories we mean seemingly marginal episodes within consistent and chronological written narratives (Bamberg \& Georgakopolou, 2008; cf. narrative identity in McAdams \& McLean, 2013). People utilise small stories to sustain self-narrated stability. These kinds of small stories may reveal something pivotal about the respondents' experiences related to the meaning they find in life.

The following three limitations of the narrative material are recognised. First, the respondents may have written largely in a tone implying that they were part of the deserving poor as there were only a few accounts that included controversial hardships, such as alcohol abuse as a personal problem or theft, or alternatively behaviours connected to the undeserving poor, such as laziness and benefit fraud. Second, the original narratives from 2006 were mainly produced by female respondents. The follow-up accounts from 2012 have more or less the same gender distribution. We learned about gendered poverty experiences from previous studies that poor men plan their future for only a short period or lack a future orientation entirely. Men also experience more profound feelings of worthlessness than women do (Hansen, 2018; Isola, Siukola, \& Kukkonen, 2019). Third, we have made the abstractions of the findings, being aware that they may not include some aspects of the broad spectrum of experiences and that there are some exceptions that the material also includes that we have not covered in this study. These limitations should be kept in mind when interpreting the findings.

\section{The Process of Analysis}

The focus of this article is on the social and/or psychological implications of prolonged poverty and the domains in which these implications take place. They are analysed through the experiences narrated in autobiographical accounts. Subsequently, the analysis is contextualised by the narrative passages or small stories, each of them containing something about meaning in life (see Supplementary Materials, p. 3). Analysis and interpretation follow a hermeneutical spiral, whereby understanding is accumulated in an interrelated process of contextualisation, reflection, (re)interpretation and integration. The third last mentioned aspects (reflection, interpretation and integration) are brought into play particularly at the end of analysis, when the findings are filtered through the conceptualization of modes of being (Arendt, 1958/1998). Thus a multi-stage analysis proceeds in five stages and is displayed in Figure $1{ }^{1}$

The material was first coded (during Stage 1) using a directed content analysis (Chase, 2011, pp. 421-422, 425; Hsieh \& Shannon, 2005, p. 1281) that followed an analytical process focused on meaning-in-life: consisting of coherence, significance, and purpose. In addition to these, incoherence and insignificance were created as codes to address negative dimensions of the aforementioned elements. Narrative passages about purpose were excluded from the follow-up analysis as they were extremely thinly present in the accounts. Bringing up decent citizens, an ecological lifestyle, faith in God, or a belief in a better life in the secular afterlife emerged as examples of a source of purpose. Sensing purpose and its relationship with short-term and long-term goals are briefly dealt with in the discussion part of this paper.

The second round of the analysis (Stage 2) was focused on longitudinal within-group comparisons, that is, passages or small stories dealing with coherence, significance, and their negative dimensions from the 2006 material were compared to those written in 2012. Then (Stage 3) the contents were categorised into the three domains in which meaning in life is constructed, deconstructed and reconstructed when in prolonged poverty: a sense of time, belonging, and participation, (see key excerpts of each domain in Supplementary Materials).

\footnotetext{
1) The analytical apparatus was chosen by Anna-Maria Isola. Stages 1 and 2 were conducted by Lotta Virrankari and Stages 3 and 4 by Isola. Step 5 was carried out primarily by Isola but Virrankari and Heikki Hiilamo were included in it; as during the analysis, their perceptions of the research material were subjected to critical discussion. This kind of researcher triangulation strengthened the credibility of the analysis.
} 
Figure 1

The Process of Analysis

Coding contents: coherence, incoherence, significance, insignificance, purpose (Stage 1)

-Passages dealing with purpose were excluded from the follow-up analysis.

Intragroup analysis: longitudinal changes in coherence and significance (Stage 2)

Outlining three domains of meaning in life in persistent poverty: sense of time, belonging and participation (Stage 3)

Intergroup analysis of the contents about sense of time, belonging and participation (Stage 4)

Findings interpreted through the modes of being: labour, work, action (Stage 5)

The following themes emerged with regard to coherence and incoherence:

Sense of Time: sense of freedom; survival; everyday pursuits; lack of financial resources; getting out of financial difficulties; un/predictability of life; stress; contending with health problems; existential loneliness; external pressure; longing for getaways; endless waiting; splurge days, outlooks on the future; in/voluntary penny pinching.

The domain of the sense of time contained experiences about the rhythm of life, future outlooks, and agency beliefs. The sense of time often determined their quality of the goals in life: whether the respondents described more long-term or short-term goals; or whether they approached their goals through negative or positive feelings.

The following themes emerged with regard to significance and insignificance:

Belonging: nature; family; neighbourhood; communities; associations; society; masses; peer groups; intergroup comparisons, existential loneliness; social powerlessness.

Participation: participation in the market economy; participation in the labour market; participation in public life through communities/culture/education/political activities/doing voluntary work or other production of social value; criticizing consumerism; public appearances; intergroup interaction; (lack of) receiving recognition; recreational participation; achievements in life; creating new meanings.

The domains of belonging and participation often supported each other, as aspects of belonging provided opportunities for participation. Conversely, participation strengthened the sense of belonging. Eventually, all three domains covered participation per se, but from slightly different angles. A sense of time with its financial and health issues describes the need for (having part of) material or immaterial resources, whereas belonging refers to being part of social, natural, or imagined groups, and participation illustrates taking part in private, shared, or public activities.

Between-group comparisons (Mabbett \& Bolderson, 1999) were carried out by scrutinising the contents of the small stories of the three groups. This stage created an understanding that while the accounts of negative changes were common in the descriptions of circular time, the accounts which involved no remarkable change represented plentiful 
upward social comparisons and a balance between circular and linear time and between a sense of belonging and a lack of it. The accounts which involved positive change, in turn, were characterised by linear time, a relatively stable sense of belonging and some participation in shared activities (Stage 4). The modes of being (labour, work, and action) were integrated into the analysis to elucidate the interpretation of the findings. Table 2 combines the findings of the hermeneutical and integrated analysis (Stage 5).

Table 2

Changes and Domains of Meaning in Life

\begin{tabular}{ll}
\hline Change in meaning in life & Domains of change in persistent poverty \\
\hline Negative change & $\begin{array}{l}\text { Sense of time: circular, survival, everyday pursuits, financial goals, life is experienced as incoherent. } \\
\text { Belonging: sense of inferiority and no significant sense of belonging, social circumstances are sometimes } \\
\text { incoherent. } \\
\text { Participation: exclusion. } \\
\text { Mode of being: labour. }\end{array}$ \\
\hline Sense of time: mostly linear, financial goals, life is experienced as coherent. \\
Belonging: social circumstances are often stable, a weakening sense of belonging, upward and downward social \\
comparisons. \\
Participation: no remarkable public participation. \\
The mode of being: work. \\
Sense of time: linear, financial and some non-financial life goals, life is experienced as coherent. \\
Belonging: stable social circumstances and a significant sense of belonging, no significant social comparisons. \\
Participation: some public participation. \\
The mode of being: in between work and action. \\
\hline Positive change
\end{tabular}

In the following sections, we discuss findings in detail by starting with the most homogenous texts, that is, accounts with negative change in the quality of life, then proceeding to the accounts with no remarkable change and eventually to the accounts with positive change. Each excerpt illustrating the analysis is provided with a code; the first letter $(\mathrm{P} / \mathrm{S} / \mathrm{N})$ refers to the positive change $(\mathrm{P})$, no remarkable change $($ same $=\mathrm{S})$ or negative change $(\mathrm{N})$ in meaning in life, the number following it indicates the running number of the respondent, the letters $\mathrm{F}$ (female) or $\mathrm{M}$ (male) indicates the respondent's gender, then follows the encoding category which an excerpt falls into and the domain of change, and $2006 / 2012$ is the year in which the text was written.

\section{Findings}

\section{The Vicious Cycle of Poverty - Accounts of Negative Change}

If the situation had deteriorated over the six years, the accounts typically included a dense description of low income, external compulsions, uncertainty, worthlessness, social exclusion, short-term goals, and an uncontrollable life filled with repetitive routines. Respondents in this group repeatedly reported that they had lived in constant fear and tension with regard to the possibility of unexpected negative decisions or delays in payments.

The accounts written in 2006 were longer overall and more voluminous than those written in 2012. This is the reason we used more excerpts in this section written in 2006 than in 2012. Unlike in 2006, the accounts written in 2012 were quite silent on the experiences of significance and a sense of coherence. This alteration implies that meaning in life had decreased. Thus, it is in line with the respondents' evaluations of the negative change in the quality of life. Almost without exception, small stories within this group of narratives revolved around day-to-day objectives, or more precisely, worrying about financial and health issues. It communicates the idea that mental resources were expended on survival. 
On the one hand, life was unpredictable as at any time an unexpected expense could lead life into chaos. One had to be constantly vigilant because as one of the respondents aptly phrased it, "there is no room for negative surprises" (N1, F, 2012, incoherence, domain of sense of time). On the other hand, contrary to the aforementioned point, life was predictable due to a low income and repetitive routines. While daily budgets and monthly payment plans created coherence, the constant need to look out for risks deconstructed it. Life passively followed the same routines day after day, as described by one respondent:

Everyday life is really tough for the poor. I also classify weekends and holidays as everyday because they are just as dull. Every day I am forced to think about what I will eat tomorrow or next week. Depending on my financial situation, I buy or don't buy products. I run out of everything: food, clothes, hygiene products, furniture and every kind of necessary commodity. (N2, M, 2006, incoherence; domain of sense of time)

Life typically proceeded by stumbling through hardships. A female respondent illustrated that even her daily diet followed the same arduous pattern. Meals were predictable due to the lack of money. However, they were unpredictable due to the food selection available in food banks or on offer. Besides, as one could not afford restaurants, one never had the opportunity to get away from daily routines. Generally speaking, respondents seldom wrote that they participated in public activities such as eating in restaurants, visiting exhibitions, or volunteering. Instead, they intensively wrote about sleep disorders, which can be interpreted as an embodiment of mentally compulsive poverty. For instance, one respondent wrote: "Life is a constant struggle through everyday life. I need to take painkillers and have a good nap to keep up," (N3, F, 2012, incoherence, domain of sense of time).

The uncertainty of life and repetitive routines without the possibility for recreational participation or a mental or physical getaway from daily objectives seemed to make people vulnerable to a downward spiral that ended up in a mess where one was no longer able to dream or have far-reaching goals, and where life was constricted to the private sphere, and subsequently, social ties were frail. Life was planned one hour, day or month at a time. The goals, if they existed at all, pertained to daily activities. Achievements were not reported, except for a couple of times.

Monotonous days went by slowly, but years passed by quickly. The following extract illustrates the foregoing:

My hand is aching; I ran out of painkillers. I am afraid that I may have to wait for two hours, but then I also run out of time and I can't complete my application for income allowance tomorrow. Today we had to go to the landlord's office to agree on the rent and get the papers ready. I'm running low on food and my cat has no food. The two hundred euros from the social services office would be greatly needed. It always tends to be like this before my unemployment benefits come. (N4, F, 2006, incoherence; domain of sense of time)

Repetitive routines, an externally compulsive life and a sense of worthlessness transformed the quality of goals from seeing positive possibilities in life to merely controlling risks. Risks replaced dreams as every unknown occasion was regarded as having negative, rather than positive, potential. These were mechanisms that eroded internal and external resources or prevented them from being utilised. It was not uncommon that a life situation was so hopeless and a sense of worthlessness was so deep that, as a last resort, some of the respondents attempted to construct a sense of coherence and significance through post-mortem fantasies. The following excerpt illustrates how, in the long run, the ability to dream eludes prolonged poverty:

My life no longer matters; but so what? My dreams and belief in a better life have finally been destroyed. There were dreams in the past, but the dreams were destroyed by realities; all that remains is to minimise the suffering. (N2, M, 2012, insignificance, domain of sense of time)

What we have learned about small stories within the narratives with negative change is that in the state of negative anticipation, a sense of belonging and active participation are connected primarily to the private sphere and everyday routines. Uncertainty tends to dismantle the sense of time. Visits to public spaces diminish. On the flip side, visits to social services are emphasised, respectively. Social services are not able to compensate for a declining sense of 
significance and an increasing sense of exclusion. This is all likely to negatively affect the quality of life in persistent poverty.

\section{Balancing Between Ups and Downs - Accounts With no Remarkable Change}

The accounts with no remarkable change included dense descriptions of a lack of money, indebtedness, sickness, and psychological burden. The experienced inequality of social security was not reported in 2012 to the extent that it was in 2006. Goals explicated varied from exceedingly long-term goals, such as breaking intergenerational poverty to tangible short-term goals, yet they were almost always linked to money.

Noticeably, long-term goals, such as having home, a car, a pet, or a holiday were mentioned more frequently in 2012 than six years earlier. A female respondent wrote that: "last autumn, with a partial payment, I was able to buy a puppy, which had been our desire for years," (S2, F, 2012, significance, domains of belonging and participation).

In the following, a female respondent discloses her feelings of otherness and describes how she has an unattainable goal of setting money aside from her salary:

I feel like a welfare bum who never has money. It would be wonderful, if I could set 500 euros aside from my salary, but in reality, there is just enough money to purchase a public transportation ticket and two times in a grocery store, and then - the cycle of poverty starts all over again. (S3, F, 2012, incoherence, domains of sense of time and belonging)

Monetary goals represented belonging to and participating in consumer society. Attained monetary goals played an important role as well. They lengthened circular time more linearly on one hand and strengthened a sense of belonging to (consumer) society and participation in the market economy on the other hand.

Even if life was reckoned to be good, it also meant balancing between ups and downs. There was no large space for unexpected joys. Adjusting one's lifestyle to monetary poverty served as a tool to construct coherence. The following extract illustrates that sometimes it meant withdrawing from public spaces: "I kind of got a good feeling from running away from people. I felt anxious. Now I'm happy: I sit on my couch and I can see big trees swaying in the wind from my living room window," (S3, F, 2012, insignificance, domains of belonging and participation).

There was only a fine line between voluntary (coherence) and involuntary (incoherence) adjustments to poverty. For instance, respondents tended to choose recycled items, but the choice was often anything but free. Consumer criticism was represented as a form of participation that outstandingly increased both coherence and significance in life. Participation in resolving the conflict between the Earth's bearing capacity and global over-consumerism was experienced as important and this came the closest to sensing a purpose in life that otherwise was almost absent. Irrespective of this, a lack of money built more of a barrier than an entrance to participation. One of the respondents expressed this aptly by stating: "A poor person cannot be inspired by politics or culture, and they cannot get involved in them due to a lack of money," (S4, F, 2012, insignificance, domain of participation).

An escape from everyday routines played a great role in creating coherence. Possibilities to retreat into green spaces, linger in the woods or nurture plants with others provided a break and helped to leave financial burdens behind. This usually occurred in spaces beyond the immanent environment saturated with money. Recreational activity was possible, for instance, in nature and libraries. A female respondent phrased it as follows: "While foraging for blueberries or pottering around in my garden, I manage not to think about my finances" (S5, F, 2006, significance, domains of sense of time, belonging and participation).

While social security appeared to be unsuccessful in maintaining coherence and significance in the reported lives framed with negative anticipation, it managed to maintain coherence but failed to create a sense of significance in the reported lives filled with ups and downs. In 2012, many respondents made both downward and upward intergroup comparisons and found that the gap between being badly off and well off was deepening. It appeared as a factor that particularly reduced a sense of significance. A female respondent interpreted this by writing: "The impoverished feel that they appear useless and futile in the eyes of the wealthy. This leads to disgust and contempt for the wealthy. [...] It feeds the circle of poverty and draws a line between wealth-based social categories," (S4, F, 2012, insignificance, domain of belonging). 
Belonging to a family and experiences in nature were quite prevalently and positively present in small stories, but in line with the aforesaid, a sense of belonging to a community and particularly to society was somewhat ambivalent and underlined by upward social comparisons in a negative sense. For instance, it was reported that opportunities to demonstrate skills, participate in shared activities together with fellow citizens, and receive positive feedback from activities rarely happened. Some respondents believed that the experiences of the poor were not even worth bringing up in the public sphere. One of the most revealing thoughts comes up in one sentence: "You [a researcher] are the only one interested in our situation outside the family," (S5, F, 2012, insignificance, domains of belonging and participation).

To sum up the findings based on small stories narrated from life with no transformational changes, the Finnish welfare state seems to maintain coherence, whereas it does not enable public participation for those who remain in persistent poverty. Hence, it more or less fails to protect the parity of participation or provide sources of significance for those suffering from poverty.

\section{The Virtuous Cycle in Prolonged Poverty - Accounts With Positive Change}

If the situation had improved over the six years, the texts were characterised by better monetary circumstances, stability, satisfying social relationships, brightening prospects, and belonging to smaller or larger communities and society. Activities were carried out both in private and public spaces. Social security benefits were criticised in this group less than in others. Although basic life circumstances were interpreted to be better than they had been six years earlier, life was not yet easy. As one respondent proves: "keeping my head above water is hard work" (P1, F, 2012, incoherence; domain of sense of time).

Throughout the accounts, life was felt to be more coherent and significant than before, but the financially poor past still cast a shadow, albeit, compared to 2006, the shadow was not so dark anymore. Although it had been tough in a bygone era, the respondents tended to interpret their overcome hardships as a blessing in disguise. For instance, in the stories, the necessary refusal of luxury was later narrated as self-discipline; constant preparedness for the unpredictability of life as flexibility; and penny pinching as creativity (see meaning-making in McAdams \& McLean, 2013, p. 234). In the following, a respondent describes that imagination is a crucial resource when weaving together the new compositions of meanings:

You may think that my intent was to give the impression that there was way more money. It wasn't - things have just got new meanings, like enjoying and appreciating relationships. Namely, we still rent the flat and dream of our own cottage, and we still make a monthly budget to pay the bills, and we play the lottery too. (P2, F, 2012, significance; domain of belonging)

The capability to reconstruct meanings came into being under circumstances where hope was alive, and coherence created a bridge over temporarily chaotic conditions. This was explained as follows: "The serene episodes even give you the strength to face poverty. Poverty does not cause me to suffer in the same way as it did six years ago." (P1, F, 2012, coherence; domain of sense of time)

The constant need to control the negative potential of life had decreased, and this had released internal resources. It might have followed an upward spiral, where unpredictable but positive opportunities began to stand out from the grey mass of everyday routines. Positive encounters with people had increased. Nature served as a restorative environment. The Finnish welfare state seemed to provide its citizens with some equal opportunities for recreational activity, such as public libraries, discounts at museums, community spaces, national parks, and everyman's rights on private land. A female respondent writes: "Bathing in one of Finland's finest log saunas in a national park is also cheap. You would not think that the state [Metsähallitus] ${ }^{2}$ would provide such a framework for a nearly free holiday," (P3, F, 2012, significance; domains of participation and sense of time)

Becoming employed improved monetary resources. Equally importantly, paid work provided opportunities to participate in society and demonstrate one's competence. A male respondent wrote: "Doing the work itself raised my

2) Metsähallitus is a public administration enterprise whose duties involve managing nature conservation and hiking areas, promoting conservation and the recreational use of state land. 
self-esteem and was very rewarding. Surviving it made me believe in the future in a new way," (P4, M, 2012, significance, domain of participation).

It is noteworthy that goals, achievements, and positive occurrences were not necessarily always associated with money. A middle-aged woman, who had faced numerous hardships in a row, found it significant to partake in a socially rehabilitative work activity, which she regarded as work without mentioning that she was not actually paid for it. While carrying out this work activity, she took on a particular responsibility that let her feel like a needed member of the community, a significant individual. It revealed that a sense of significance is constructed reciprocally between people through action. At the end of the account, the writer even challenges the reader:

I ask you one thing about your job: Have you ever gone to work happily? I do it every morning. And it's wonderful to work when you're happy to go there. And you can really give your life to others. But I have to tell you, I get more from them [clients at the service center] than they get from me. But it's a nice feeling when even one of them thinks they can give me something-so then they have had a good day, even just one good day. (P4, F, 2012, significance; domains of participation and belonging)

Universal spaces beyond the monetary sphere (Eskelinen, Hirvilammi, \& Venäläinen, 2020)-such as community activities, free education, inexpensive hobbies, low-cost or cost-free cultural possibilities, libraries, swimming pools, and national parks strengthen meaning in life by providing sources of recognition and a sense of significance. They also may provide a getaway from everyday routines and also help in combining bits and pieces into meaning in life.

\section{Discussion}

Irrespective of relatively generous social security, prolonged monetary poverty in a developed welfare state such as Finland may lead to a vicious cycle. It undermines experienced meaningfulness in life in all its facets (coherence, significance, purpose) within the domains of a sense of time, a sense of belonging, and public participation. Zhao and Tomm (2018) have outlined the vicious cycle of scarcity which disturbs life in many domains and leads eventually to impulse sensitivity, risk-aversion, and a myopic life. This equates with our finding: that prolonged poverty 1) turns aspirations from long-term to short-term goals and frames life as something characterised by negative anticipation and a circular sense of time. Based on our analysis, we also note that 2) a sense of belonging and 3) public participation are domains in which construction, reconstruction, and deconstruction of meaning in life take place. This is illustrated in Figure 2 by using the metaphor of the vicious cycle of poverty.

When embroiled in prolonged poverty, an individual may gradually be tied to the present, and in the long run, linear time may be replaced completely by circular time. Interpreted in Arendt's (1958/1998) terms, the quintessence of persistent poverty is the mode of labour wherein life primarily takes place in a private space and follows the parameters of reproduction and cycles. In these shrinking circles, everyday life easily wraps itself up in negative anticipation, losing its coherence and significance. Circular time allows only a little space for recovery from financial, social, and psychological burdens. It also limits imaginative mental activity that would buffer difficulties and heal the feelings of otherness and inferiority, among others.

In the mode of work, a sense of time is not as fatal as in the mode of labour. Linear time is concretised through having some instrument-orientated goals in the near future, albeit life is otherwise mostly defined by everyday pursuits. Short pauses from exhaustive everyday life are geared towards cost-free recreational activities, such as activities in national parks and libraries and cultural happenings. At best, a developed welfare state maintains the mode of work in prolonged poverty, specifically since the social benefit scheme in some respects fills the need for coherence. Particularly accounts with no remarkable or positive change in the quality of life gave evidence to this finding. 
Figure 2

The Vicious Cycle of Poverty and Domains of Meaning in Life

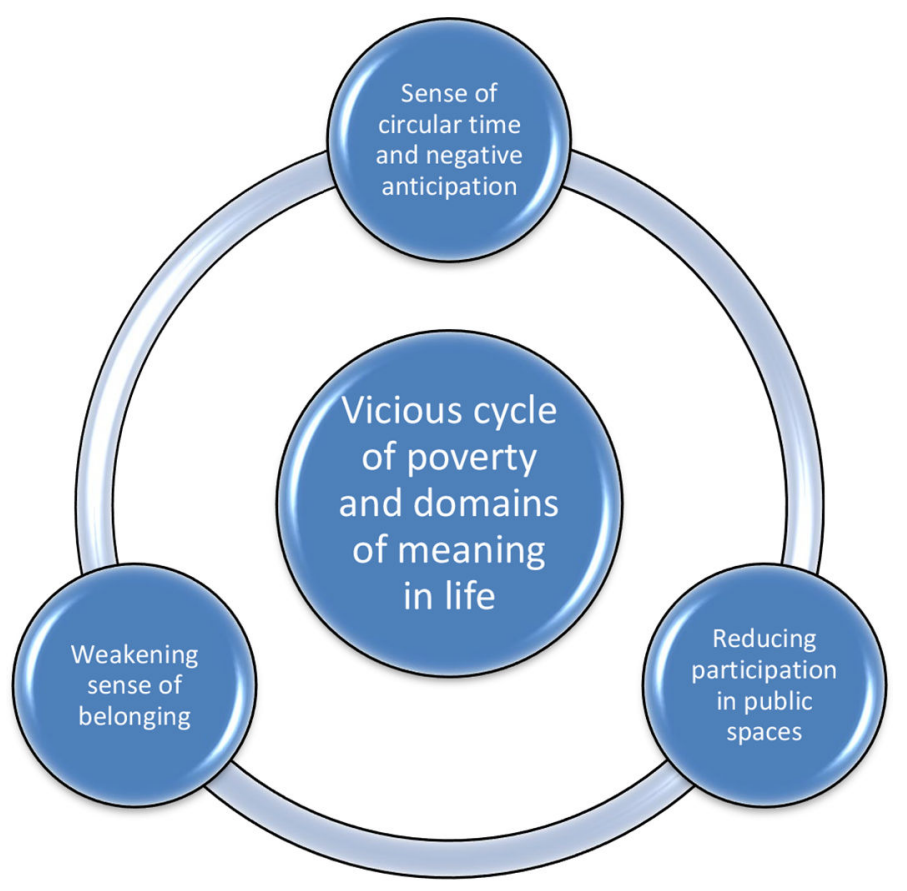

Prolonged poverty consumes resources so that people cannot keep up with social relationships that would maintain a sense of belonging. Poor people tend to interpret that their position in society is that of "second-class citizens" or "social welfare cases." Nevertheless, relatively stable circumstances in life, albeit financially limited, and sensing belonging with people who share the same values may orientate people to subsume positive attributions into their lives. A sense of belonging to culture or nature may heal negative feelings derived from experienced inequality and injustice. This is a salient domain where meaningfulness and the mode of work are maintained amidst monetary poverty. Again, accounts with a positive change in the quality of life supported this finding as well as accounts with no remarkable change, with the difference that the latter group included detrimental upward comparisons while the former did not.

While financial and concrete goals were common, a sense of purpose was thinly expressed overall in the narratives of this study. Recognition-how individuals are rewarded for their lives and activities-is associated with having a purpose in life. As even accounts with a positive change in the quality of life lack a sense of purpose to a considerable extent, we have reason to assume that recognition and the parity of participation (Fraser, 2009) are threatened in persistent poverty. It reduces participation in meaning-making processes, shared activities, and public discussions. Even in a developed welfare state, prolonged poverty pervasively and fundamentally prevents levelling up to a mode of action in which recognition would be shared in self-determined participation in public activities (Isola, Siukola, \& Kukkonen, 2019; Laitinen, 2011, pp. 328-333). Participation in public spaces is an important domain for the meaning in life to emerge. A welfare state could provide opportunities to construct meaning in life for people suffering from persistent monetary poverty. Coherence is a lifeline that is maintained by a comprehensive and manageable social security scheme yet entering a mode of action calls for universal social policy actions that nurture serendipitous circumstances and nourish meaningfulness in life.

A stimulus for this article was a perception that people experienced meaninglessness in persistent poverty. We employed longitudinal narrative material to scrutinize this preliminary perception and developed a method for a longitudinal narrative analysis based on a phenomenological approach. The analysis verifies that prolonged poverty affects sense of time, participation, belonging, and recognition. It also demonstrates that a longitudinal research setting strengthens the explanatory power of narrative materials. Finally, it may deepen the understanding of the role of social 
security and policies of participation in shaping a sense of meaningfulness, mode of being and human behaviour in prolonged poverty.

Funding: The European Social Fund [S20220], Social insurance institution of Finland, and The Finnish Foundation for Municipal Development have funded

the study.

Acknowledgments: We would like to thank Aatu Ruohonen and Henna Puromäki for organising and preparing the material for analysis.

Competing Interests: The authors have declared that no competing interests exist.

Data Availability: For this study, two datasets are freely available (Isola, Larivaara, \& Mikkonen, 2006; Isola, 2012).

\section{Supplementary Materials}

All the research data for this study are archived in the Finnish Social Science Data Archive according to the General Data Protection Regulation (GDPR). The materials of FSD2413 Everyday experiences of poverty: Self-administered writings 2006 are available at http://urn.fi/urn:nbn:fi:fsd:T-FSD2413 and FSD2795 Everyday experiences of poverty 2012: Follow-up study available at http://urn.fi/ urn:nbn:fi:fsd:T-FSD2795 The accounts used in the article are: P016, P024, P070, P077, P078, P088, P130, P137, P138, P165, P168, P212, S038, S040, S056, S066, S079, S083, S085, S087, S090, S093, S098, S119, S155, S156, S164, S172, S180, S181, S213, S229, S242, S270, S278, S309. The ethics working group for the Finnish institute for health and welfare (THL) supported the research design on $1^{\text {st }}$ of March 2012 (An extract from the minutes of the ethics working group § 454).

The Supplementary Materials file contains 1) the encoding process of the longitudinal narrative material, 2) domains of meaning in life, 3) and 8-10 key excerpts of each domain to illustrate the analysis process (for access see Index of Supplementary Materials below).

\section{Index of Supplementary Materials}

Isola, A.-M., Larivaara, M., \& Mikkonen, J. (2006). Everyday experiences of poverty: Self-administered writings 2006 (FSD2413) [Research data]. Finnish Social Science Data Archive. http://urn.fi/urn:nbn:fi:fsd:T-FSD2413

Isola, A.-M. (2012). Everyday experiences of poverty 2012: Follow-up study (FSD2795) [Research data]. Finnish Social Science Data Archive. http://urn.fi/urn:nbn:fi:fsd:T-FSD2795

Isola, A.-M., Virrankari, L., \& Hiilamo, H. (2021). Supplementary materials to "On social and psychological consequences of prolonged poverty-A longitudinal narrative study from Finland" [Additional information]. PsychOpen GOLD.

https://doi.org/10.23668/psycharchives.5262

\section{References}

Akfirat, S., Polat, F. Ç., \& Yetim, U. (2016). How the poor deal with their own poverty: A social psychological analysis from the social identity perspective. Social Indicators Research, 127, 413-433. https://doi.org/10.1007/s11205-015-0953-2

Antonovsky, A. (1979). Health, stress and coping. San Francisco, CA, USA: Jossey-Bass.

Antonovsky, A. (1987). Unravelling the mystery of health: How people manage stress and stay well. San Francisco, CA, USA: JosseyBass.

Anttonen, A., \& Sipilä, J. (2012). Universalism and the challenge of diversity. In A. Anttonen, L. Häikiö, \& K. Stefánsson (Eds.), Welfare state, universalism, and diversity (pp. 16-41). Cheltenham, United Kingdom: Edward Elgar.

Arendt, H. (1998). The human condition (2nd ed.). London, United Kingdom: University of Chicago Press. (Original work published 1958)

Bamberg, M., \& Georgakopolou, A. (2008). Small stories as a new perspective in narrative and identity. Text \& Talk, 28(3), 377-396. https://doi.org/10.1515/TEXT.2008.018

Banker, S., Bhanot, S. P., \& Deshpande, A. (2020). Poverty identity and preference for challenge: Evidence from the U.S. and India. Journal of Economic Psychology, 76, Article 102214. https://doi.org/10.1016/j.joep.2019.102214 
Beresford, P., Green, D., Lister, R., \& Woodward, K. (1999). Poverty first hand: Poor people speak for themselves. London, United Kingdom: Child Poverty Action Group.

Bernard, M., Braunschweig, G., Fegg, M. J., \& Borasio, G. D. (2015). Meaning in life and perceived quality of life in Switzerland: Results of a representative survey in German, French and Italian regions. Health and Quality of Life Outcomes, 13 , Article 160. https://doi.org/10.1186/s12955-015-0353-y

Bertrand, M., Mullainathan, S., \& Shafir, E. (2004). A behavioral-economics view of poverty. The American Economic Review, 94(2), 419-423. https://doi.org/10.1257/0002828041302019

Chase, S. E. (2011). Narrative inquiry. In N. K. Denzin \& Y. S. Lincoln (Eds.), The SAGE handbook of qualitative research (pp. 421-434). Thousand Oaks, CA, USA: SAGE.

The constitution of Finland. (1999). The Constitution of Finland 11 June 1999 (731/1999, amendments up to 817/2018 included). Retrieved from https://www.finlex.fi/en/laki/kaannokset/1999/en19990731.pdf

Deci, E. L., \& Ryan, R. M. (1985). Intrinsic motivation and self-determination in human behavior. New York, NY, USA: Plenum Press.

Desmond, M., \& Travis, A. (2018). Political consequences of survival strategies among the urban poor. American Sociological Review, 83(5), 869-896. https://doi.org/10.1177/0003122418792836

Eskelinen, T., Hirvilammi, T., \& Venäläinen, J. (2020). Introduction: Community economies and social transformation with, within and beyond the welfare state. In T. Eskelinen, T. Hirvilammi, \& J. Venäläinen (Eds.), Enacting community economies within a welfare state. London, United Kingdom: MayFlyBooks. Retrieved from http://urn.fi/URN:NBN:fi:jyu-202003182442

Esping-Andersen, G. (1990). The three worlds of welfare capitalism. Princeton, NJ, USA: Princeton University Press.

Fraser, N. (2009). Scales of justice: Reimagining political space in a globalizing world. Cambridge, United Kingdom: Columbia University Press.

Hall, C. C., Zhao, J., \& Shafir, E. (2014). Self-affirmation among the poor: Cognitive and behavioral implications. Psychological Science, 25(2), 619-625. https://doi.org/10.1177/0956797613510949

Hansen, H. C. (2018). Recognition and gendered identity constructions in labour activation. International fournal of Social Welfare, 27(2), 186-196. https://doi.org/10.1111/ijsw.12294

Hastrup, K. (1987). Presenting the past: Reflections on myth and history. Folk: fournal of the Danish Ethnographic Society, $29,257-263$.

Haushofer, J., \& Fehr, E. (2014). On the psychology of poverty. Science, 344(6186), 862-867. https://doi.org/10.1126/science.1232491

Hellman, C. M. E., Monni, M., \& Alanko, A. M. (2017). Declaring, shepherding, managing: The welfare state ethos in Finnish government programmes 1950-2015. Research on Finnish Society, 10, 9-22. Retrieved from https://doi.org/10.51815/fjsr.110762

Hiilamo, H. (2012). Rethinking the role of church in a socio-democratic welfare state. The International fournal of Sociology and Social Policy, 32(7-8), 401-414. https://doi.org/10.1108/01443331211249048

Hiilamo, H., Kangas, O., Fritzell, J., Kvist, J., \& Palme, J. (2013). Recipe for a better life: Experiences from the Nordic countries. Helsinki, Finland: CMI Martti Ahtisaari Centre.

Hsieh, H. F., \& Shannon, S. E. (2005). Three approaches to qualitative content analysis. Qualitative Health Research, 15(9), 1277-1288. https://doi.org/10.1177/1049732305276687

Isola, A.-M., Siukola, R., \& Kukkonen, M. (2019). Gendered experiences of poverty and recognition in the Finnish Welfare State. NORA, 27(3), 152-165. https://doi.org/10.1080/08038740.2019.1604570

Kettunen, P. (2006). The tension between the social and the economic - A historical perspective on a welfare state. In J. Ojala, J. Eloranta, \& J. Jalava (Eds.), The road to prosperity: An economic history of Finland (pp. 285-313). Helsinki, Finland: Finnish Literature Society.

Kiander, J. (2005). The Nordic welfare state in the 1990s: Consequences of disinflation and fiscal consolidation in the three Nordic EU countries (Ezoneplus Working Paper, No. 13D). Retrieved from https://www.econstor.eu/bitstream/10419/31953/1/480654255.pdf

Korpi, W., \& Palme, J. (1998). The paradox of redistribution and strategies of equality: Welfare state institutions, inequality, and poverty in the Western countries. American Sociological Review, 63(5), 661-687. https://doi.org/10.2307/2657333

Kosonen, P. (1993). Finnish model and the welfare state in crisis. Helsinki, Finland: Renvall Institute, University of Helsinki. Retrieved from http://hdl.handle.net/10224/3560

Kuivalainen, S., \& Nelson, K. (2012). Eroding minimum income protection in the Nordic countries? Reassessing the Nordic model of social assistance. In J. Kvist, J. Fritzell, B. Hvinden, \& O. Kangas (Eds.), Changing social equality: The Nordic welfare model in the 21st Century (pp. 69-88). Cambridge, United Kingdom: Policy Press. 
Kuivalainen, S., \& Niemelä, M. (2010). From universalism to selectivism? The ideational turn the antipoverty policies in Finland. fournal of European Social Policy, 20(3), 263-276. https://doi.org/10.1177/0958928710364432

Laitinen, A. (2011). Recognition, acknowledgement, and acceptance. In H. Ikäheimo \& A. Laitinen (Eds.), Recognition and social ontology (pp. 309-348). Boston, MA, USA: Brill.

Larsen, C. A. (2013). Structural unemployment as a new social risk in the Nordic countries - A critical reassessment. In I. Harsløf \& R. Ulmestig (Eds.), Changing social risks and social policy responses in the Nordic welfare states (pp. 113-139). London, United Kingdom: Palgrave Macmillan UK.

Leis-Peters, A. (2014). Hidden by civil society and religion? Diaconal institutions as welfare providers in the growing Swedish welfare state. A Journal of Church and State, 56(1), 105-127. https://doi.org/10.1093/jcs/cst134

Lister, R. (2004). A politics of recognition and respect: Involving people with experience of poverty in decision-making that affects their lives. In J. Andersen \& B. Siim (Eds.), The Politics of inclusion and empowerment: Gender, class and citizenship (pp. 116-138). London, United Kingdom: Palgrave Macmillan UK.

Mabbett, D., \& Bolderson, H. (1999). Theories and methods in comparative social policy. In J. Clasen (Ed.), Comparative social policy: Concepts, theories and methods (pp. 34-56). Malden, MA, USA: Wiley-Blackwell.

Mani, A., Mullainathan, S., Shafir, E., \& Zhao, J. (2013). Poverty impedes cognitive function. Science, 341(6149), 976-980. https://doi.org/10.1126/science.1238041

Marmot, M. (2015). The health gap: The challenge of an unequal world. Lancet, 386(10011), 2442-2444. https://doi.org/10.1016/S0140-6736(15)00150-6

Martela, F. (2017). Can good life be measured? The dimensions and measurability of a life worth living. In G. Brulé \& F. Maggino (Eds.), Metrics of subjective well-being: Limits and improvements (pp. 21-42) (Happiness Studies Book Series: No. 4). Cham, Switzerland: Springer.

Martela, F., \& Ryan, R. (2016). The benefits of benevolence: Basic psychological needs, beneficence, and the enhancement of wellbeing. Journal of Personality, 84(6), 750-764. https://doi.org/10.1111/jopy.12215

Martela, F., Ryan, R., \& Steger, M. (2018). Meaningfulness as satisfaction of autonomy, competence, relatedness, and beneficence: Comparing the four satisfactions and positive affect as predictors of meaning in life. fournal of Happiness Studies, 19, $1261-1282$. https://doi.org/10.1007/s10902-017-9869-7

Martela, F., \& Steger, M. F. (2016). The three meanings of meaning in life: Distinguishing coherence, purpose, and significance. The Journal of Positive Psychology, 11(5), 531-545. https://doi.org/10.1080/17439760.2015.1137623

Mattila, M., Rapeli, L., Wass, H., \& Söderlund, P. (2017). Health and political engagement. Abingdon, United Kingdom: Routledge.

McAdams, D. P., \& McLean, K. (2013). Narrative identity. Current Directions in Psychological Science, 22(3), 233-238. https://doi.org/10.1177/0963721413475622

Ministry of Economic Affairs and Employment of Finland. (2019). Long-term unemployment. August 2019. Retrieved from https://www.temtyollisyyskatsaus.fi/graph/tkat/tkat.aspx?lang=en\&top=2\&ssid=1910140922088\&sub=24

Mood, C., \& Jonsson, J. O. (2016). The social consequences of poverty: An empirical test on longitudinal data. Social Indicators Research, 127, 633-652. https://doi.org/10.1007/s11205-015-0983-9

Official Statistics of Finland (OSF). (2006). Total statistics on income distribution [e-publication]. ISSN = 1797-3279. 2006, 3. Pienituloisuus on pitkittynyt [Low-income periods have lengthened] (in Finnish), Statistics Finland [accessed: 10.10.2019]. Retrieved from https://www.stat.fi/til/tjkt/2006/tjkt_2006_2007-12-21_kat_003_fi.html

Pemberton, S., Fahmy, E., Sutton, E., \& Bell, K. (2016). Navigating the stigmatised identities of poverty in austere times: Resisting and responding to narratives of personal failure. Critical Social Policy, 36(1), 21-37. https://doi.org/10.1177/0261018315601799

Reutter, L. I., Stewart, M. J., Veenstra, G., Love, R., Raphael, D., \& Makwarimba, E. (2009). "Who do they think we are, anyway?”: Perceptions of and responses to poverty stigma. Qualitative Health Research, 19(3), 297-311. https://doi.org/10.1177/1049732308330246

Ryan, R. M., \& Deci, E. L. (2000). Self-determination theory and the facilitation of intrinsic motivation, social development, and wellbeing. The American Psychologist, 55(1), 68-78. https://doi.org/10.1037/0003-066X.55.1.68

Schweiger, G. (2013). Recognition and social exclusion: A recognition-theoretical exploration of poverty in Europe. Ethical Perspectives, 20(4), 529-554.

Stefánsson, K. (2012). What is in a word? Universalism, ideology and practice. In A. Anttonen, L. Häikiö, \& K. Stefansson (Eds.), Welfare state, universalism and diversity (pp. 42-68). Cheltenham, United Kingdom: Edward Elgar. 
Tajfel, H. (Ed.). (1978). Differentiation between social groups: Studies in the social psychology of intergroup relations. London, United Kingdom: Academic Press.

Townsend, P. (1979). Poverty in the United Kingdom: A survey of household resources and standards of living. London, United Kingdom:

Penguin Books.

Walker, R. (2014). The shame of poverty. Oxford, United Kingdom: Oxford University Press.

Zhao, J., \& Tomm, B. (2018). Psychological responses to scarcity. Oxford, United Kingdom: Oxford University Press.

\section{Appendix}

\section{Table A.1}

Background Information on the Respondents' Sex, Age, Labour Status, Family Relations and Housing

\begin{tabular}{|c|c|c|c|c|c|c|}
\hline \multirow{2}{*}{$\frac{\text { Background }}{\text { Year }}$} & \multicolumn{2}{|c|}{ Negative change } & \multicolumn{2}{|c|}{ No remarkable change } & \multicolumn{2}{|c|}{ Positive change } \\
\hline & 2012 & 2006 & 2012 & 2006 & 2012 & 2006 \\
\hline \multicolumn{7}{|l|}{ Sex } \\
\hline Female & 9 & & 9 & & 9 & \\
\hline Male & 3 & & 3 & & 3 & \\
\hline \multicolumn{7}{|l|}{ Age } \\
\hline 30 or under & 0 & & 1 & & 1 & \\
\hline $31-40$ & 2 & & 1 & & 3 & \\
\hline $41-50$ & 3 & & 3 & & 2 & \\
\hline $51-60$ & 3 & & 2 & & 4 & \\
\hline Over 60 & 2 & & 2 & & 1 & \\
\hline Unknown & 2 & & 3 & & 1 & \\
\hline \multicolumn{7}{|l|}{ Labour status } \\
\hline Employed & 0 & 1 & 5 & 2 & 9 & 3 \\
\hline Unemployed & 7 & 7 & 2 & 3 & 0 & 3 \\
\hline Part-time employee & 1 & 2 & 1 & 1 & 0 & 0 \\
\hline Pensioner & 2 & 1 & 2 & 3 & 1 & 1 \\
\hline Student & 1 & 1 & 1 & 1 & 1 & 2 \\
\hline Unknown & 1 & 0 & 1 & 2 & 1 & 3 \\
\hline \multicolumn{7}{|l|}{ Family relations } \\
\hline Spouse and children & 5 & 7 & 4 & 3 & 5 & 4 \\
\hline Children & 5 & 3 & 3 & 4 & 3 & 4 \\
\hline Spouse & 1 & 1 & 1 & 1 & 2 & 3 \\
\hline Widow & 0 & 0 & 1 & 1 & 0 & 0 \\
\hline Unknown & 1 & 1 & 3 & 3 & 2 & 1 \\
\hline \multicolumn{7}{|l|}{ Housing } \\
\hline Own & 0 & 1 & 3 & 3 & 4 & 1 \\
\hline Rented & 5 & 8 & 4 & 5 & 4 & 7 \\
\hline Right-of-occupancy & 0 & 0 & 1 & 1 & 1 & 0 \\
\hline dwelling & 7 & 3 & 4 & 3 & 3 & 4 \\
\hline Unknown & & & & & & \\
\hline
\end{tabular}

